\title{
TEMPUS Project "eSience"
}

\author{
http://dx.doi.org/10.3991/ijoe.v10i5.4209 \\ Thomas Zimmer \\ University of Bordeaux, Talence, France
}

This special focus of the International Journal of Online Engineering (iJOE) is dedicated to five selected papers from REV2014, the $11^{\text {th }}$ International Conference on Remote Engineering and Virtual Instrumentation hold in Porto, Portugal, from 26-28 February 2014. These selected papers are describing the current progress of work of the euro-maghrebian TEMPUS project eSience. The main goal of this TEMPUS project is the creation of a network of remote labs in the Maghrebian countries Morocco, Tunisia and Algeria. Sixteen (16) different partners, (11 academic institutions, 2 associations and 3 companies) are part of the consortium. The principal objectives of this project are: (i) Build a network of working remote labs in Maghreb, (ii) Investigation and implementation of stateof-the art solution, (iii) Establish best praxis, (iv) Connection to other remote lab systems and networks. The corresponding learning content is dedicated to engineering education covering a broad range of fields such as electronics, automation and control, optics and physics. The project started on October 2012 and has duration of 3 years. The budget is about $1 \mathrm{M} €$.

Thomas Zimmer, Project Coordinator 